\section{УДК 796.015.134.386-057.875. 37.037 doi: 10.15330/fcult.33.188-193}

\section{Adriana Albu, Ionuţ Onose, Raluca Mihaela Hodorcă, Beatrice Abalaşei}

\title{
FOOD HABITS OF THE STUDENTS FROM THE SPORTS PROGRAM HIGHSCHOOL IN SUCEAVA
}

\begin{abstract}
Мета. Дослідження особливостей харчування студентів спортивної гімназії. Матеріал і методи: дослідження проводилося на групі з 122 учнів спортивної школи, де проводилися спортивні заняття та теоретичні заняття. Студенти заповнювали щзотижневу анкету частоти споживання їжі. Результати. Прийом ранкової їжі щзоденно у 36,36\% молодих людей зі значними відмінностями на користь тих, хто займається спортом. Смаком є щзоденна присутність у 42,62\% учнів з незначними відмінностями залежно від профілю. Щотижневий прийом м'яса курки становить переважно 2-3 рази (46,28\%), а яйця - 2-3 рази (38,01\%) з незначними відмінностями. Сушені овочі присутні в меню, особливо 1 / тиждень (43,80\%) і щзоденний хліб (52,89\%). Висновки: Харчування не пристосоване до підвищених потреб студентів, які займаються спортивною діяльністю, щуо є тривожною.
\end{abstract}

Ключові слова: спорт, звичка харчування.

Objectives of the study: knowledge of the students of the Sports High School; the appreciation of the differences that do not arise between the nutrition of the students from the sport profile and the theoretical ones; reporting students' nutrition to rational nutrition standards. Nutrition is an external factor that contributes to the development of children and young people and to optimizing the motor performance of students who practice performance sports. Material and method. The study was conducted on a group of 122 students from a Sports Highschool where there were sports classes and theoretical classes. Students completed a weekly frequency questionnaire on food consumption. Results. The morning meal intake is present daily at $36.36 \%$ of young people with significant differences in favor of those from the sports program. The taste is the daily presence in 42,62\% of pupils with insignificant differences depending on the profile. The weekly intake of chicken meat is mostly 2-3 times (46.28\%) and the eggs still 2-3 times (38.01\%) with insignificant differences. Dried vegetables are present in menus, especially 1/week (43.80\%) and daily bread (52.89\%). Conclusions. Nutrition is not adapted to the increased needs of students who practice sports performance, which is worrying.

Keywords: sports, eating habits.

Introduction. Balanced nutrition plays an important role in the growth / development of children and young people. It becomes even more important to those who practice sports performance. In addressing the issue of nutrition, we must take into account two essential aspects of the dietary habits of the population and the specific needs for the teenager who performs the sport of performance.

The first aspect to be considered is that related to the eating habits of the students' families surveyed and the possibility of changing them. In a study conducted in Romania on adolescents in the rural area there is a change of diet compared to that of their grandparents and their parents. From food produced in own household it went to those bought in stores. However, culinary traditions are preserved at religious celebrations or other family events (Baciu, 2015).

In the area of Moldova the situation is different, there being a strong anchorage in the traditions of the students' families. In a study conducted in the city of Iasi, high school students, there are statistically significant differences between maternal education and nutrition. Even if the mother has a university education level, there is no essential change in eating habits. The maternal educational level has been taken into account because the mother is the one who is concerned with purchasing food and preparing menus, so the information they have is essential (Albu, Rada, Albu, Cracana, Lupu, 2011). Another difficult problem is related to the absence of changes in dietary habits based on income per family member, a result obtained in studies conducted in the Moldavian area. Even if money is not a problem, eating habits change very little or do not change (Indrei, Rada, Albu, Cracana, Albu, 2011). 
Another element to be studied is that of the body's needs for sporting activity. Practicing performance sports requires the development of muscle mass and skeleton. In this context, protein requirements are increased and it is necessary to ensure the supply of quality products. These are foods that contain all the essential amino acids in balanced quantities, that is to say, food products of animal origin (milk, cheese, eggs, meat) (Raţu, Doliş, Murariu, Hodorca, Onose and Usturoi, 2018).

Vegetable food products (vegetables, fruits, dried legumes, cereals) contain large amounts of vegetable protein that are customized by the appearance of a limiting amino acid (present in smaller quantities). In order to ensure growth and stimulate sport performance, it is necessary to consume larger quantities of these products. Unfortunately, this excess can be associated with the increase in body weight and the change in body appearance or body composition (Abalasei and Trofin, 2016).

In the literature there are articles that recommend different protein intakes depending on the sex of the athlete. In Brasil, male weight gainers recommend a protein intake of $14.5 \%$ of the total caloric intake and only $13.7 \%$ for females, in Greece swimmers have a $17.4 \%$ contribution to male and 17.6\% of protein to the female (Hima, Meenu, and Priti, 2017).

Basically, the athlete nutrition specialist should be part of the training team for the future sporting performance. Otherwise the pupil's health condition and sports performance can be seriously affected.

Objectives of the study: knowledge of the students of the Sports High School; the appreciation of the differences that do not arise between the nutrition of the students from the sport profile and the theoretical ones; reporting students' nutrition to rational nutrition standards.

Material and method. The study was conducted on a group of 121 students from the Sports High School in Suceava. 62 students from the sports profile $(51.23 \%)$ and $59(48.76 \%)$ from the theoretical profile were examined. Young people aged between 15 and 17 are in the 10th grade and 11th grade. A questionnaire was put on these youngsters with questions about the food intake at the beginning of the meal and at the frequency with which they appear in the chicken menu every week, eggs, peas / beans and bread. In the questions "you serve breakfast" and you get used to having a snack at school "the variants of answer are: every day - often - rarely - never. When asked "how many times a week you eat" chicken, eggs, dried legumes, bread the answer variants are: zero -1 date $-2 / 3$ times $-4 / 6$ times - daily. The results were processed using the Pearson test.

Results. Two major aspects of morning food / snack food intake and frequency with which certain foods appear in the menus appear in the menus.

The grocery / snack input is important for all students, but essential for those who practice sports. They will start exercises with exhausted energy reserves in the morning which is not a positive element.

Daily nutritional intake is $36.36 \%$ adolescents daily, plus another $22.31 \%$ who choose the option often. Basically, in $60 \%$ of cases, eating breakfast is a stimulating element for school and sports activity (tabl. 1).

Table 1

Food intake in the morning

\begin{tabular}{|l|l|l|l|l|}
\hline & Everyday & Often & Rarely & Never \\
\hline Sports Profile & 29 & 15 & 16 & 2 \\
Theoretical & 15 & 12 & 22 & 10 \\
$\begin{array}{l}\text { Profile } \\
\text { Total no. }\end{array}$ & 44 & 27 & 38 & 12 \\
$\%$ & 36.36 & 22.31 & 31.40 & 9.91 \\
\hline
\end{tabular}


Draw attention to $9.91 \%$ of young people who choose the option never. The calculated differences are statistically significant at a $\mathrm{p}<0.05\left(f=3, \chi^{2}=10,944\right)$ and are oriented towards a better distribution of food in the daily program to the students of the sporting profile.

Higher energy needs also cover with a snack at school. There are $44.62 \%$ daily responses and $33.88 \%$ responses often. Basically, in almost $80 \%$ of the situations, the taste is present in the nutrition of the questioned pupils (tabl. 2).

Table 2

The presence of the snack in students' menus

\begin{tabular}{|l|l|l|l|l|}
\hline & Everyday & Often & Rarely & Never \\
\hline $\begin{array}{l}\text { Sports Profile } \\
\text { Theoretical }\end{array}$ & 24 & 28 & 9 & 1 \\
$\begin{array}{l}\text { Profile } \\
\text { Total no. }\end{array}$ & 30 & 13 & 15 & 1 \\
$\%$ & 54 & 41 & 24 & 2 \\
\hline
\end{tabular}

The calculated differences are statistically insignificant $\left(\mathrm{p}>0.05, f=3, \chi^{2}=7.654\right)$ and are oriented towards the existence of similar eating habits for students in the study group. This is an aspect that must be carefully watched because those in the sport profile have increased energy needs.

The second aspect studied is the frequency with which certain foods appear in weekly menus. These are products of animal origin (chicken, eggs) and vegetable (peas / beans and bread).

Chicken is present in menus, especially $2-3$ times (46.28\%), which is worrying because more and more chicken is currently consumed in our country. Students in the sports profile will not provide the necessary protein for harmonious muscular development. I draw attention to $3.30 \%$ of adolescents who do not consume or consume it only once per week (tabl. 3).

Table 3

\begin{tabular}{|l|l|l|l|l|l|}
\hline & Zero & Once/week & $\begin{array}{l}2-3 \text { times/ } \\
\text { week }\end{array}$ & $\begin{array}{l}4-6 \\
\text { times / } \\
\text { week }\end{array}$ & Daily \\
\hline $\begin{array}{l}\text { Sports Profile } \\
\text { Theoretical }\end{array}$ & 1 & 10 & 30 & 13 & 8 \\
$\begin{array}{l}\text { Profile } \\
\text { Total no. }\end{array}$ & 4 & 11 & 26 & 10 & 9 \\
$\%$ & 3.30 & 21 & 56 & 23 & 17 \\
$\%$
\end{tabular}

The calculated differences are statistically insignificant $\left(\mathrm{p}>0.05, f=4, \chi^{2}=1.731\right)$ and reveal the existence of similar eating habits, which is not positive because the needs of the students from the two studied profiles are different.

The problematic meat supply can be compensated by the presence of eggs in the menus. Teens can consume 6-7 eggs a week, but such a response only occurs in over $16 \%$ of cases (4-6 times $9.09 \%$ answers and $7.43 \%$ daily). I attract the attention of $18.18 \%$ of young people who mark the zero variant, which is inappropriate because the eggs are an excellent source of high quality protein (tabl. 4). 
Table 4

The frequency with which eggs appear in menus

\begin{tabular}{|c|c|c|c|c|c|}
\hline & Zero & Once/week & $\begin{array}{l}2-3 \text { times/ } \\
\text { week }\end{array}$ & $\begin{array}{l}4-6 \text { times / } \\
\text { week }\end{array}$ & Daily \\
\hline Sports Profile & 8 & 21 & 24 & 4 & 5 \\
\hline $\begin{array}{l}\text { Theoretical } \\
\text { Profile }\end{array}$ & 14 & 12 & 22 & 7 & 4 \\
\hline $\begin{array}{l}\text { Total no. } \\
\%\end{array}$ & $\begin{array}{l}22 \\
18.18 \\
\end{array}$ & $\begin{array}{l}33 \\
27.27\end{array}$ & $\begin{array}{l}46 \\
38.01 \\
\end{array}$ & $\begin{array}{l}11 \\
9.09 \\
\end{array}$ & $\begin{array}{l}9 \\
7.43 \\
\end{array}$ \\
\hline
\end{tabular}

The calculated differences are statistically insignificant $\left(\mathrm{p}>0.05, f=4, \chi^{2}=5.032\right)$, which reveals an inadequacy of nutrition to the increased needs of the body of the students who practice sports.

There must also be vegetable products that are rich in protein and carbohydrates. The proteins in these products have an average biological value, being deficient in certain essential amino acids.

Dried vegetables (peas, beans) are high in protein, but their biological value is average, so they are not the best option for sports students. Dominant consumption is once a week $(43.80 \%)$, which does not mean a major protein intake. The calculated differences are statistically significant at a $\mathrm{p}<0.05\left(f=4, \chi^{2}=11.732\right)$ and guide the existence of a higher intake of dried legumes in the students of the sport profile.

Reducing intake is an important element for the Romanian population, where beans have long been considered a traditional food. It is now consuming less and less, so it is possible to change food habits (tabl. 5).

Table 5

Weekly intake of dried leguminous vegetables, \%

\begin{tabular}{|l|l|l|l|}
\hline & Sports Profile & Theoretical Profile & Total \\
\hline Zero & 17 & 27 & $44-36.36$ \\
Once / week & 26 & 27 & $53-43.80$ \\
2-3 times /week & 15 & 4 & $19-15.70$ \\
4-6 times / week & 3 & - & $3-2.47$ \\
Daily & 1 & 1 & $2-1.65$ \\
\hline
\end{tabular}

Bread and cereal products are rich in plant proteins and carbohydrates, giving the body a substantial caloric intake. It is important to appreciate the frequency with which they appear in the menus, because in the cure of slimming the first gesture is to drastically reduce the consumption of these products, arriving until their elimination from the diet. In the study group, the daily intake of bread is recognized by half of the young people. There are $9.91 \%$ responses of 4-6 times that are acceptable. Practically, in $40 \%$ of cases we face problems because adolescents consume it $2-3$ times $(16.52 \%)$ or 1 time $(11.57 \%)$ per week. I draw attention to $9.09 \%$ negative responses, also present in the sport profile, the calculated differences being statistically insignificant ( $\left.\mathrm{p}>0.05, f=4, \chi^{2}=2.711\right)$ (tabel 6).

Table 6

Bread consumption, \%

\begin{tabular}{|l|l|l|l|}
\hline & Sports Profile & Theoretical Profile & Total \\
\hline Zero & 6 & 5 & $11-9.09$ \\
Once / week & 8 & 6 & $14-11.57$ \\
2-3 times /week & 13 & 7 & $20-16.52$ \\
4-6 times / week & 6 & 6 & $12-9.91$ \\
Daily & 29 & 35 & $64-52.89$ \\
\hline
\end{tabular}


Discussions. The student who intensively practices a sports activity has increased nutritional needs. It is also important to have the correct distribution of food in the daily program, the morning meal and snack foods become essential. In the study group breakfast is present in most cases every day or often, there are rare or never answers. The calculated differences are statistically significant, which leads to a better distribution of food over a day, with no increase in intake, which is worrying. In a study conducted in Romania, $9.09 \%$ of male negative responses to male students and $15.59 \%$ of female responses. The study was conducted compared to a group of teenagers surveyed in 1977 when $18.18 \%$ of male gender responses and $13.79 \%$ of female responses (Baciu, 2011). The results indicate an increase in adolescent interest in morning food intake.

In a study conducted on teenagers with anemia in Egypt, results are coming to the attention of specialists in the field. In teenagers with anemia, breakfast is present daily in $11.7 \%$ of youngsters, with $55.0 \%$ of girls absent. In the control group (no anemia), the daily intake reaches $54.2 \%$ and the absent drops to $3.3 \%$, with statistically significant differences (Naglaa and Marwa, 2018).

The situation can be remedied with a snack at school. Students in the study group frequently use this snack, but the differences are statistically insignificant, so there is no increase in interest in snacking at athletes. The evaluation of the adolescents from the Sports Program in Iasi versus young people from a theoretical high school highlights the existence of similar results. Daily intake is present in $55.73 \%$ of young people, rarely in $20.21 \%$ of cases, and the one absent in $2.62 \%$ of cases. Unfortunately, in this case, there are no statistically significant differences, so it is a common food habit of the students in the study group (Albu, Onose, Negrea, Hodorca and Cracana, 2015).

The Alexandria adolescent study highlights the presence of snacking daily in $17.3 \%$ of cases and often in 54.6\% of cases (Emara, Mehanna, Ashour, Koura and Shatat, 2018). Young people resort to snack, something to be supported by consistent nutritional education programs.

Chicken is present in most students' dropouts, attracting the attention of $3.30 \%$ of young people who choose the zero option and $17.35 \%$ of those who mark the one-time option. It is an interesting answer for the Moldavian area where a lot of chicken is consumed. Adult teenagers in Sudan have 1.9\% negative responses with $42.9 \%$ responses at 1 . In that area, a little chicken is consumed (daily in just $6.2 \%$ of cases), which draws attention to special dietary habits in different parts of the world (Misaa, Somiya Gutbi and Siham, 2018).

Eggs are present in daily menus (result adapted to rational nutrition norms) in only $7.43 \%$ of cases. In the study of adolescents in Iasi, such a result occurs in $6.56 \%$ of cases, so it is still inappropriate (Albu, Onose, Negrea, Hodorca and Cracana, 2015). Eggs are rich in quality protein in lipids, vitamins and minerals, but the caloric intake is modest $(171 \mathrm{Kcal} /$ $100 \mathrm{~g}$ of product). Nutritional education programs should be done correctly, starting from the problems that arise rather than the ideas of some politicians (giving fruit in schools).

Dried vegetables are becoming less consumed, even though beans have long been regarded as a traditional product. Basically, changes in eating habits occur, but often due to problems with the time required for food processing.

The bread is rich in vegetable protein, carbohydrates and offers a high caloric intake. I draw the attention of $9.09 \%$ of young people who mark zero and $11.57 \%$ of students who mark the 1 st variant. In the study conducted in Sudan there are no answers, and the ones once a week are present only in 3.30\% cases (Misaa, Somiya Gutbi and Siham, 2018).

There are differences in the eating habits of the population, differences that need to be addressed by specialists in the field.

Conclusions. Nutritional education intervention of students practicing performance sports is necessary. Breakfast is present in most of the students at the sports program, but it's 
just about better distribution of food in the day schedule and not the increase in the quantities consumed. The input of animal products (chicken and eggs) is similar to the two studied profiles. In this context, there is no assurance of the need for quality proteins that contribute to the development of muscle mass. Vegetable products are present in modest quantities (dried vegetables) or appropriate (bread) but they do not provide all the necessary nutrients.

The sport profile requires the intervention of a nutritionist specializing in sports nutrition, to guide the nutrition of the pupils to the particular nutritional requirements required by intensive sports activity.

\section{References}

1. Abalasei B. and Trofin F., 2016. Considerations on the correlation between real body and body image, Timisoara Physical Education and Rehabilitation Journal, vol. 9, Issue 16, pp. 7-12.

2. Albu A., Onose I., Negrea M., Hodorca R.M.and Cracana I., 2015,Rev.Sport si Societate, vol.15, Issue 2, pp. 202-208.

3. Albu A., Rada C., Albu M., Cracana I., Lupu C., 2011, Corrèlation niveau educationnel maternel alimentation à un lot d'adolescents du lycèe"Dimitrie Cantemir" de Iasi, in Mondialization du comportement alimentaire et l'obésité, coordinateurs Glavce C., Milici N., Rovillé-Sausse si Iancu E., Bucuresti: Editura Academiei Romane, pp. 124-128.

4. Baciu A., 2015, Aspecte ale comportamentului alimentar al unei comunitati rurale din Romania, in Natura si Omul, coordonatori: Iancu E., Glavce C. si Baciu A., Ploiesti: BIOEDIT, pp. 12-21.

5. Baciu A., 2011, Anthropological - medical aspects of feeding behavior of children in modern society, Review of Global \medicine and Health Research, vol. 2, nr. 1, pp. 79-99.

6. Emara R., Mehanna A. A., Ashour A., Koura M. and Shatat H. Z., 2018, Dietary habits and age at menarche in relation to body weight among preparatory school girls in Alexandria, Journal of High Institute of Public Health, 48(1), 9-17.

7. Hima, B.M., Meenu, D., and Priti, R.L., 2017, Nutritional status of athletes: a review, International Journal of Physiology, Nutrition and Physical Education, 2(2), 895-904.

8. Indrei L.L., Rada C., Albu A., Cracana I., Albu A., 2011, Corelatia alimentatie - venit pe membru de familie la un lot de adolescenti de la Liceul "Dimitrie Cantemir" din Iasi, Revista Medico-Chirurgicala, vol. 115, nr. 1, pp. 181-185.

9. Misaa M.A.A., Somiya Gutbi S.M., and Siham M.O.G.,2018, Assessment of nutritional status of the adolescents (13-18 years) studying in secondary schools in Elhafeir Area-dangle locality - northen state 2018, Indian Journal of Applied Research, 8(8), 1-5.

10. Naglaa K.A.H and Marwa M.A.O.,2018, Life style risk factors of Iron deficiency anemia among adolescent's girls, International journal of Nursing didactics, 8: (10) October, pp. 18-28.

11. Rațu R.N., Doliș M.G., Murariu O.C., Hodorcă R.M., Onose I. and Usturoi M.G., 2018, Studies regarding quantitative evaluation of milk proteins gathered from different animal breeds as source for a healthy nourishment of athletes, Proceedings of ICU 2018 The impact of Sport and Physical Education Science on Today's Society, EDlearning, pp. 303-308.

\section{Цитування на цю статтю:}

Adriana Albu, Ionuţ Onose, Raluca Mihaela Hodorcă, Beatrice Abalaşei. Food Habits of Students from the Sports Program Highschool in Suceava. Вісник Прикарпатського університету. Серія: Фізична культура. 2019 Берез 26; 33: 188-193

\begin{tabular}{|c|c|}
\hline Відомості про автора: & Information about the author: \\
\hline $\begin{array}{l}\text { Адріана Албу - Університет медицини і фармації } \\
\text { iм. Г.Т. Попа (Румунія) }\end{array}$ & $\begin{array}{l}\text { Adriana Albu - "Grigore T. Popa" University of } \\
\text { Medicine and Pharmacy (Iasi, Romania) }\end{array}$ \\
\hline \multicolumn{2}{|l|}{ e-mail: info@eu-medstudy.com } \\
\hline $\begin{array}{l}\text { Iоніч Онозе - Ясський університет ім. Олександра } \\
\text { Іоана Кузи (Ясси, Румунія) }\end{array}$ & $\begin{array}{l}\text { Ionuţ Onose - "Alexandru Ioan Cuza" University of } \\
\text { Iasi (Iasi, Romania) }\end{array}$ \\
\hline $\begin{array}{l}\text { Ралука Міхаела Ходорои - Ясський університет } \\
\text { ім. Олександра Іоана Кузи (Ясси, Румунія) }\end{array}$ & $\begin{array}{l}\text { Raluca Mihaela Hodorcă - "Alexandru Ioan Cuza" } \\
\text { University of Iasi (Iasi, Romania) }\end{array}$ \\
\hline \multicolumn{2}{|l|}{ e-mail: raluca.hodorca@yahoo.com } \\
\hline $\begin{array}{l}\text { Беатріс Абаласй - Ясський університет } \\
\text { iм. Олександра Іоана Кузи (Ясси, Румунія) }\end{array}$ & $\begin{array}{l}\text { Beatrice Abalaşei - "Alexandru Ioan Cuza"' Univer- } \\
\text { sity of Iasi (Iasi, Romania) }\end{array}$ \\
\hline
\end{tabular}

